\title{
Up Against The Wall: The Effects of Climate Warming on Soil Microbial Diversity and The Potential for Feedbacks to The Carbon Cycle
}

\section{Grace Pold and Kristen M. DeAngelis *}

Microbiology Department, University of Massachusetts Amherst, Amherst, MA 01003, USA;

E-Mail: apold@microbio.umass.edu

* Author to whom correspondence should be addressed; E-Mail: deangelis@microbio.umass.edu; Tel.: +1-413-577-4669; Fax: +1-413-545-1578.

Received: 15 April 2013; in revised form: 27 April 2013 / Accepted: 17 May 2013/

Published: 3 June 2013

\begin{abstract}
Earth's climate is warming, and there is evidence that increased temperature alters soil $\mathrm{C}$ cycling, which may result in a self-reinforcing (positive), microbial mediated feedback to the climate system. Though soil microbes are major drivers of soil $\mathrm{C}$ cycling, we lack an understanding of how temperature affects SOM decomposition. Numerous studies have explored, to differing degrees, the extent to which climate change may affect biodiversity. While there is ample evidence that community diversity begets ecosystem stability and resilience, we know of keystone species that perform functions whose effects far outweigh their relative abundance. In this paper, we first review the meaning of microbial diversity and how it relates to ecosystem function, then conduct a literature review of field-based climate warming studies that have made some measure of microbial diversity. Finally, we explore how measures of diversity may yield a larger, more complete picture of climate warming effects on microbial communities, and how this may translate to altered carbon cycling and greenhouse gas emissions. While warming effects seem to be ecosystem-specific, the lack of observable consistency between measures is due in some part to the diversity in measures of microbial diversity.
\end{abstract}

Keywords: climate warming; keystone species; long-term field study; metagenomics; microbial community diversity; niche theory; richness; soil; stress response 


\section{Introduction}

Soil is one of the most diverse habitats on Earth, but also one of the least characterized in terms of the identification and ecological roles of the microbiota. Soils also contain the largest repository of organic carbon (C) in the terrestrial biosphere, and the activities of heterotrophic soil organisms are responsible for large portions of the annual $\mathrm{CO}_{2}$ flux to the atmosphere. A substantial fraction of soil $\mathrm{C}$ occurs in relatively complex organic compounds, which tend to be resistant to decomposition under current environmental conditions. It is likely that soil organic matter (SOM) decay will change under future climate, and of the approximately $3100 \mathrm{Pg}$ of carbon stored in soils, an estimated $5 \%$ will be lost in the next decade due to warming [1,2]. These estimates illustrate the vulnerability of this stored $\mathrm{C}$, though the mechanisms of how the $\mathrm{C}$ will be lost are not well understood.

Microorganisms catalyze key processes related to greenhouse gas fluxes between soils and the atmosphere [3,4], but the role that microbes will play in the evolution of Earth's climate over decades to centuries is undefined. A more complete understanding of how global warming will affect carbon-cycle feedbacks to the climate system is central to model projections of future climate [5]. Preliminary data from the longest-running soil warming study at Harvard Forest suggests that over 20 years of warming results in a loss of labile, microbial available $\mathrm{C}$ that puts the soil microbes "up against the wall" metaphorically, forcing adaptation that will affect global $\mathrm{C}$ cycling [6-8]. Advances in molecular biological methods, including high-throughput sequencing $[9,10]$ combined with manipulative field experiments such as in situ soil warming $[11,12]$ make it possible to identify and model relationships between microbial communities and climate system feedbacks. This paper focuses on understanding how climate warming affects soil microbial community diversity, and its impacts on ecosystem function.

Two non-mutually exclusive diversity hypotheses developed for macroecology [13] can be applied to describe observed changes in carbon cycling with climate warming. The first community diversity hypothesis suggests that an overall increase in diversity has resulted in communities more resistant to higher and more extreme temperatures. This hypothesis is based on evidence that in general, more diverse communities are more resistant to stress and more efficient [13-15], possibly because taxonomic and functional richness often go side by side [16,17]. The alternative hypothesis is somewhat complementary: the keystone species hypothesis suggests that the increase in populations specifically associated with a function, such as the ability to degrade more recalcitrant or previously physically protected soil carbon, is responsible for observed changes in carbon cycling. The increased relative (or absolute) abundance of these functional populations may be independent of changes in overall diversity. In the next sections, we explore the support for each hypothesis, and then evaluate the literature for evidence of diversity or keystone functions in previously published climate warming studies.

\section{Functional Implications of Diversity}

The community diversity hypothesis predicts that diversity-taxonomic diversity, but especially species count (richness) - has a value in and of itself. More diverse communities are not only more productive [18], but they tend to be better able to maintain ecological functions under stress (resistance) and more able to recover function when the stressor is relieved (resilience) $[19,20]$. These patterns are often explained using niche theory; each organism has a niche defined by the range of environmental conditions it requires to survive, but only realizes a fraction of this potential because of 
competition with other organisms which share some portion of this niche [21]. Organisms may only survive under a narrow set of conditions (specialists), or have a broad niche (generalists). In general, more diverse communities are better at taking advantage of the resource space (i.e., range of conditions present in an environment), and therefore are able to more completely and efficiently convert resources into biomass [13,18].

Environment dictates total resource space, and therefore carrying capacity of the ecosystem, but also the range of niches available to organisms. Furthermore, because organisms differ in their susceptibility to stressors, such as drought and temperature [22-24], changes in the environment affect the relative abundance of organisms in an environment. If lower species richness is indicative of reduced niche overlap, then species loss should have a disproportionately high impact on ecosystem function in species-poor (depauperate) communities. In other words, species-rich assemblages may have another phylotype ready to expand its realized niche into the newly-vacated portion of its fundamental niche, but species-poor ones may not [25]. Functional stability is also expected to be favored by a high proportion of generalists, or in a community with diverse metabolisms represented [15,26]. Furthermore, if diverse communities are more resistant to changes in function, then they may prevent changes in the ecosystem itself, allowing for less resistant organisms to recolonize once the disturbance passes [19]. For example, due to variation in environmental tolerances, an initially diverse arbuscular mycorrhizal fungal community may be necessary to survive an extended drought and maintain a soil structure resistant to erosion [27,28].

Although the community diversity hypothesis is rooted in much theory, it originated in macroecology, which considers communities with apparently lower richness and functional redundancy than soil microbial communities. Therefore, it is unclear how well this hypothesis can predict soil microbial responses to warming. For example, while Hol et al. found that reducing microbial species richness through dilution increased plant biomass and nutritional quality [29], Wertz et al. found no reduction in nitrification or denitrification activity when they diluted soils, and richness did not increase resistance to or recovery from a short period of high temperatures [30]. However, Wertz and colleagues did confirm that functional groups differed in their sensitivity to warming; this knowledge can help us identify steps in the carbon cycle, for example, where ecosystem function is most likely to break down. This is particularly important in the context of the cross-feeding which characterizes many detritivorous pathways [31]. If these syntrophic interactions are highly-specific or dependent on a specific organism, we expect loss of diversity to reduce productivity or some other measure of ecosystem function.

As a counter point to the community diversity hypothesis, the keystone species hypothesis predicts that some taxa have a disproportionate effect on ecosystem function. For example, Leptospirillum group III only accounted for $10 \%$ of the cells in an acid mine drainage biofilm, but since this organism was the only one with a complete nitrogen fixation pathway, it likely supplied all the nitrogen used by the community [32]. Single phylotypes can be important for ecosystem function in much richer communities too [33]; while members of the Desulfosporosinus only accounted for $0.006 \%$ of the microbial population in a peatland soil, they were responsible for the majority of soil sulfate reduction, competing effectively with methanogens for resources and producing the less potent greenhouse gas carbon dioxide instead [34]. These results are consistent with a meta-analysis of studies that manipulated soil microbial diversity, in which Nielsen et al. [31] found that increasing species diversity only improves ecosystem function in species poor $(<10$ species $)$, but not species rich, soils. 
The authors concluded that changes in community composition and loss of keystone species are likely to have a stronger effect on ecosystem function than loss of richness, per se.

Together, these findings imply that sequential loss of taxa in initially rich habitats such as soil should not lead to a significant loss of ecosystem function until one of these keystone species is lost. These patterns open the door to the possibility that a reduction in diversity may lead to a loss of functional stability. Thus, while many soil microbes may appear to be functionally redundant, they differ in their environmental tolerance [35-39], and substrate preferences [40,41], and in some instances may be the sole mediators of an ecological process.

\section{Warming Effects on Diversity}

Climate warming is an abiotic stressor, with the potential to alter the diversity of the soil microbial community, and therefore the range of processes they complete [15]. Of particular interest is the effect of elevated temperatures on soil organic matter decomposition, which a growing number of studies are addressing. A small subset of these incorporate some measure of microbial community diversity, using a biochemical approach such as phospholipid fatty acid (PLFA) analysis, or a molecular approach such as community fingerprinting or sequencing, with some metric of microbial activity or biomass (Table 1). These two approaches can provide different — though complementary—views of microbial communities.

Table 1. Geographic and climatic data for sites compared in this paper.

\begin{tabular}{|c|c|c|c|c|c|}
\hline Biome & Site & Coordinates & MAT & MAP & References \\
\hline Tall-grass prairie & $\begin{array}{l}\text { Kessler Farm Field } \\
\text { Laboratory, Washington OK }\end{array}$ & $\begin{array}{l}34.98^{\circ} \mathrm{N} \\
97.52^{\circ} \mathrm{W}\end{array}$ & $16.3^{\circ} \mathrm{C}$ & $967 \mathrm{~mm}$ & {$[42-44]$} \\
\hline Old field grassland & $\begin{array}{l}\text { National Ecological Research } \\
\text { Park, Oak Ridge TN }\end{array}$ & $\begin{array}{l}35.90^{\circ} \mathrm{N} \\
84.33^{\circ} \mathrm{W}\end{array}$ & $14.9^{\circ} \mathrm{C}$ & $1360 \mathrm{~mm}$ & {$[45,46]$} \\
\hline $\begin{array}{l}\text { Mixed hardwood } \\
\text { forest }\end{array}$ & $\begin{array}{l}\text { Harvard Forest LTER, } \\
\text { Petersham MA }\end{array}$ & $\begin{array}{l}42.5^{\circ} \mathrm{N} \\
72.18^{\circ} \mathrm{W}\end{array}$ & $7.6^{\circ} \mathrm{C}$ & $1100 \mathrm{~mm}$ & [6] \\
\hline $\begin{array}{l}\text { Temperate } \\
\text { mountain forest }\end{array}$ & $\begin{array}{l}\text { North Tyrolean Limestone } \\
\text { Alps, Austria }\end{array}$ & $\begin{array}{l}47.58^{\circ} \mathrm{N} \\
11.64^{\circ} \mathrm{E}\end{array}$ & $5.7^{\circ} \mathrm{C}$ & $1480 \mathrm{~mm}$ & [47] \\
\hline Taiga boreal forest & Delta Junction, AK & $\begin{array}{l}63.92^{\circ} \mathrm{N} \\
145.73^{\circ} \mathrm{W}\end{array}$ & $-2.6^{\circ} \mathrm{C}$ & $1290 \mathrm{~mm}$ & [48-50] \\
\hline $\begin{array}{l}\text { Sub-Arctic blanket } \\
\text { bog }\end{array}$ & Abisko, Sweden & $\begin{array}{l}68.21^{\circ} \mathrm{N} \\
18.49^{\circ} \mathrm{E}\end{array}$ & $-0.6^{\circ} \mathrm{C}$ & $352 \mathrm{~mm}$ & {$[51,52]$} \\
\hline Sub-Arctic heath & Abisko, Sweden & $\begin{array}{l}68.19^{\circ} \mathrm{N} \\
18.51^{\circ} \mathrm{E}\end{array}$ & $-0.6^{\circ} \mathrm{C}$ & $352 \mathrm{~mm}$ & [53] \\
\hline Sub-Antarctic & Signy Island & $\begin{array}{l}60.72^{\circ} \mathrm{S} \\
45.38^{\circ} \mathrm{W}\end{array}$ & $-2{ }^{\circ} \mathrm{C}$ & $400 \mathrm{~mm}$ & [54-56] \\
\hline Sub-Antarctic & Falkland Islands & $\begin{array}{l}51^{\circ} \mathrm{S} \\
59.05^{\circ} \mathrm{W}\end{array}$ & $7.9^{\circ} \mathrm{C}$ & $575 \mathrm{~mm}$ & [54-56] \\
\hline Antarctic & Anchorage Island & $\begin{array}{l}67.57^{\circ} \mathrm{S} \\
68.13^{\circ} \mathrm{W}\end{array}$ & $-2{ }^{\circ} \mathrm{C}$ & $500 \mathrm{~mm}$ & [54-56] \\
\hline
\end{tabular}


The net effect of warming on soil microbes tends to be increased microbial activity over the short term, which translates to increased soil respiration [12,57,58]. An early lab incubation study of temperate forest soils demonstrated that this increase in activity can be accompanied by shifts in microbial biomass and community composition [59]. However, of the field studies conducted that ran for three years or more [57,58], few that observed increases in microbial activity also examined changes in microbial community composition (Table 2). Despite this, some general patterns are beginning to emerge. For example, there is evidence that not all soil microbial communities respond similarly to warming, with warming more likely to have a negative effect on microbial abundance (density) in cool, dry locations [60]. Furthermore, response to warming is rapid, and perhaps more rapid than shifts in community structure. Therefore it is likely that some of the warming effect is attributable to changes in the active fraction of the biomass, rather than the community's constituents $[59,61,62]$. Here, we will discuss how warming has affected microbial community diversity, biomass, and activity in a series of long-term warming experiments in different biomes, before turning to potential drivers of these changes and the consequences for the carbon cycle.

Long-term experiments at the Kessler Farm Field Laboratory (KFFL) in the plains of central Oklahoma found increased diversity under warming and drought, suggesting that warming may have somehow "primed" the community to be more resilient and resistant to further disturbance. These tallgrass prairie plots have been continuously warmed $2{ }^{\circ} \mathrm{C}$ above ambient since 1999 , with half of each plot also being clipped annually [42]. In the second and third full years of treatment, Zhang et al. found that warming treatment increased fungal and decreased bacterial biomass as measured using PLFA analysis, but only in unclipped plots, demonstrating the importance of plant effects in driving the response. Furthermore, the authors found that while there was no effect of warming on total microbial biomass, net $\mathrm{N}$ mineralization decreased and there was a significant shift in the substrate utilization profiles, indicating a change in the metabolic capacity of the community. In years five to seven of the KFFL soil warming study, Sheik et al. found the effect of warming on microbial community structure and activity was strongly dependent on whether or not the site was facing drought [43]. In regular precipitation years, warming increased population size, but that the community was less rich and diverse. Under drought, however, warming decreased population size and increased its diversity, richness, and evenness without any change in community composition. The authors suggested that shifts in relative abundance of extant species rather than recruitment of novel ones drives ecosystem function under altered climate.

As a follow up to this study, Zhou et al. used high-throughput technologies to determine the functional significance of these shifts in diversity and potential feedback response of microbial communities to eight years of warming [44]. Pyrosequencing of the 16S ribosomal RNA gene showed a large shift in the community composition, and despite data collection in a non-drought year, higher microbial abundance using GeoChip and PLFA analysis [44]. However, not all populations involved in SOM decay were equally stimulated by warming; while those involved in the degradation of labile compounds such as starch, hemicellulose, cellulose, and chitin were stimulated, those involved in lignin degradation were not, and activity of the ligninase peroxidase even decreased. Soil respiration increased at this site, but its temperature sensitivity decreased, suggesting a weakened positive feedback to the climate system. Since there was a shift in the taxa detected without a change in 
diversity at this site, this implies immigration or recruitment of microbes from the rare biosphere may be responsible for the shift towards labile substrate use.

Table 2. In situ field studies examining the effect of warming on soil microbial community ${ }^{\mathrm{a}}$.

\begin{tabular}{|c|c|c|c|c|c|}
\hline Biome & Location & Heating $^{\mathbf{b}}$ & Duration & Key Findings ${ }^{\mathbf{c}}$ & Ref. \\
\hline \multirow{3}{*}{$\begin{array}{l}\text { Tall-grass } \\
\text { prairie }\end{array}$} & \multirow{3}{*}{$\begin{array}{l}\text { Kessler Farm Field } \\
\text { Lab, Washington OK }\end{array}$} & \multirow{3}{*}{$\begin{array}{l}+1.8-2.7^{\circ} \mathrm{C} \\
\left(2{ }^{\circ} \mathrm{C}\right), \mathrm{IR} \\
\text { continuous }\end{array}$} & $2-3$ years & $\begin{array}{l}\text { MC: Strong overall shift in absence of clipping } \\
\text { MB: No overall change in biomass; increased fungi } \\
\text { MA: No change in C mineralization }\end{array}$ & [42] \\
\hline & & & $4-6$ years & $\begin{array}{l}\text { MC: Increased diversity but no shift under } \\
\text { drought; strong overall shift if above-normal } \\
\text { precipitation } \\
\text { MB: Decreased population size in drought years; } \\
\text { increased if above-normal precipitation. MA: n.d. }\end{array}$ & [43] \\
\hline & & & 8 years & $\begin{array}{l}\text { MC: Strong overall shift } \\
\text { MB: Increased microbial PLFA's; non-significant } \\
\text { increase in bacterial and fungal biomass, no } \\
\text { change in F:B ratio } \\
\text { MA: Increased C mineralization; increased labile C- } \\
\text { degrading genes, unchanged recalcitrant C-degrading } \\
\text { genes }\end{array}$ & [44] \\
\hline \multirow{2}{*}{$\begin{array}{l}\text { Old field } \\
\text { grassland }\end{array}$} & \multirow{2}{*}{$\begin{array}{l}\text { National Ecological } \\
\text { Research Park, Oak } \\
\text { Ridge TN }\end{array}$} & \multirow{2}{*}{$\begin{array}{l}+3{ }^{\circ} \mathrm{C}, \mathrm{OTC} \\
\text { continuous }\end{array}$} & $2-3$ years & $\begin{array}{l}\text { MC: Strong overall shift } \\
\text { MB: Increased Firmicutes, decreased Gram- } \\
\text { negative bacteria, arbuscular mycorrhizal fungi } \\
\text { and saprophytic fungi } \\
\text { MA: n.d. }\end{array}$ & [45] \\
\hline & & & 4 years & $\begin{array}{l}\text { MC: Strong overall shift } \\
\text { MB: Increased fungal abundance; decreased } \\
\text { bacteria (QPCR) } \\
\text { MA: n.d. }\end{array}$ & [46] \\
\hline $\begin{array}{l}\text { Mixed } \\
\text { hardwood } \\
\text { forest }\end{array}$ & $\begin{array}{l}\text { Harvard Forest } \\
\text { LTER, Petersham } \\
\text { MA }\end{array}$ & $\begin{array}{l}+5{ }^{\circ} \mathrm{C}, \mathrm{HC} \\
\text { continuous }\end{array}$ & 12 years & $\begin{array}{l}\text { MC: Strong overall shift } \\
\text { MB: Decreased microbial biomass, decreased } \\
\text { fungi, increased Gram-positives and } \\
\text { Actinomycetes } \\
\text { MA: Decreased biomass-specific respiration }\end{array}$ & {$[6]$} \\
\hline $\begin{array}{l}\text { Temperate } \\
\text { mountain } \\
\text { forest }\end{array}$ & $\begin{array}{l}\text { North Tyrolean } \\
\text { Limestone Alps, } \\
\text { Austria }\end{array}$ & $\begin{array}{l}+4{ }^{\circ} \mathrm{C}, \mathrm{HC} \\
\text { snow-free } \\
\text { seasons only }\end{array}$ & $4-6$ years & $\begin{array}{l}\text { MC: No overall changes } \\
\text { MB: No overall change in biomass; decreased } \\
\text { Actinomycetes and Gram-negatives. } \\
\text { MA: Increased biomass-specific respiration, } \\
\text { stress biomarkers }\end{array}$ & [47] \\
\hline
\end{tabular}


Table 2. Cont.

\begin{tabular}{|c|c|c|c|c|c|}
\hline Biome & Location & Heating $^{b}$ & Duration & Key Findings ${ }^{\mathrm{c}}$ & Ref. \\
\hline $\begin{array}{l}\text { Taiga } \\
\text { boreal } \\
\text { forest }\end{array}$ & Delta Junction, AK & $\begin{array}{c}+0.5^{\circ} \mathrm{C}, \mathrm{CTC}, \\
\text { continuous }\end{array}$ & $0-3$ years & $\begin{array}{l}\text { MC: Change in active (BrdU) fungi } \\
\text { MB: }>50 \% \text { decrease in fungi and bacteria } \\
\text { MA: Lower chitinase, lower respiration rate in } \\
\text { late growing season. }\end{array}$ & [48] \\
\hline $\begin{array}{l}\text { Taiga } \\
\text { boreal } \\
\text { forest }\end{array}$ & Delta Junction, AK & $\begin{array}{c}+1.2{ }^{\circ} \mathrm{C}, \mathrm{CTC} \\
\text { growing season } \\
\text { only }\end{array}$ & $0-3$ years & $\begin{array}{l}\text { MC: No overall changes in fungal community } \\
\text { MB: n.d. } \\
\text { M.A.:Increased } \beta \text {-glucosidase and N-acetyl- } \\
\text { glucosaminidase activity; no change in } \\
\text { respiration }\end{array}$ & [49] \\
\hline $\begin{array}{l}\text { Sub- } \\
\text { Arctic }\end{array}$ & $\begin{array}{c}\text { Blanket bog, Abisko, } \\
\text { Sweden }\end{array}$ & $\begin{array}{c}+0.3-2.8^{\circ} \mathrm{C} \\
\left(1^{\circ} \mathrm{C}\right), \mathrm{OTC} \\
\text { seasonal }\end{array}$ & 9 years & $\begin{array}{l}\text { MC: No overall changes } \\
\text { MB: Decreased microbial biomass under summer } \\
\text { warming } \\
\text { MA: No change in soil peptidase activity; increased } \\
\text { N-flux }\end{array}$ & {$[52]$} \\
\hline $\begin{array}{l}\text { Sub- } \\
\text { Arctic }\end{array}$ & $\begin{array}{l}\text { Sub-Arctic heath, } \\
\text { Abisco, Sweden }\end{array}$ & $\begin{array}{c}+1.2-2{ }^{\circ} \mathrm{C}, \\
\text { OTC, snow-free } \\
\text { seasons only }\end{array}$ & 15 years & $\begin{array}{l}\text { MC: No overall changes } \\
\text { MB: decreased microbial biomass } C \text {; increased } \\
\text { fungal:bacterial ratio }{ }^{\mathbf{e}} \text {; no change in } \mathrm{G}+\text { : } \\
\text { G-MA: n.d. }\end{array}$ & [53] \\
\hline $\begin{array}{l}\text { Antarctic } \\
\text { and sub- } \\
\text { Antarctic }\end{array}$ & $\begin{array}{l}\text { Falkland, Signy,\& } \\
\text { Anchorage Islands }\end{array}$ & $\begin{array}{l}+0.5-2{ }^{\circ} \mathrm{C}, \mathrm{OTC}, \\
\text { continuous }\end{array}$ & 3 years & $\begin{array}{l}\text { MC: No overall changes } \\
\text { MB: Increased fungi, bacteria, and ratio of } \\
\text { Alphaproteobacteria to Acidobacteria } \\
\text { MA: Increased N-cycling }\end{array}$ & {$[56]$} \\
\hline
\end{tabular}

\footnotetext{
a Studies were included in this table if they looked at microbial community composition and at least one of microbial biomass, and microbial community were examined. They must also have at least three full growing seasons of data, unless there is subsequent data from the same site to corroborate the early warming effects. ${ }^{\mathbf{b}}$ Heating methods include "OTC," passive open-top chambers; "HC," resistance heating cables; "CTC," closed-top chambers; and "IR," infrared radiators suspended $1.5 \mathrm{~m}$ off the ground. In cases where there is no feedback regulation of warming treatment, temperature is provided as a range followed by the mean treatment in brackets. " Key findings are for "MC," microbial community profiles; "MB," microbial biomass; and "MA," microbial activity, where "n.d." indicates no data for this category. ${ }^{\mathbf{d}}$ This trend observed only in treatments without clipping. ${ }^{\mathbf{e}}$ top $5 \mathrm{~cm}$ only.
}

The effects of warming on microbial processes are expected to be greatest at higher latitudes [1,63], though studies indicate that effects are mixed, and some ecosystems may in fact be more resistant to warming than originally thought. For example, in a blanket bog in northern Sweden, Weedon et al. [52] found that 9 years of seasonal $0.2-2.2{ }^{\circ} \mathrm{C}$ warming increased soil respiration, particularly from older, deeper carbon [51], and increased nitrogen cycling, but did not lead to any significant changes in vegetation [52]. However, warming did not change the DGGE profile of the microbial community or peptidase activity, but decreased the microbial abundance detected using qPCR. The relative resistance of the microbial community to elevated temperatures may reveal a tight association to plants in this 
system. This is consistent with the finding of Rinnan et al., where it took more than 15 years for $1.2-2{ }^{\circ} \mathrm{C}$ of experimental warming to affect microbial community composition in a subarctic heath at the same site [53] although addition of nitrogen at a rate designed to mimic warming-induced mineralization led to an effect sooner [64]. The authors hypothesized that nitrogen addition increased plant productivity, but there was a time delay between the increased plant productivity and support of greater microbial biomass. In a final example, after three years of continuous $0.5-2{ }^{\circ} \mathrm{C}$ warming at three sites in the Antarctic and sub-Antarctic, Yergeau et al. found no effect of warming on the rRNA profile of the community, but higher microbial abundance and Alphaproteobacteria:Acidobacteria ratio. Sequences for a number of processes were reduced under warming, including cellulose, chitin, and lignin degradation, although those for nitrogenase were higher under warming [56]. Together these results imply that the ecological functions were relatively redundant in the initial community and distributed across the phylogenetic tree, indicating both functional and phylogenetic diversity aided with the survival of the community through time. However, Allison and Treseder found that the fungal community in a taiga boreal forest of Alaska was highly-sensitive to just $0.5^{\circ} \mathrm{C}$ of seasonal warming; microbial biomass, soil respiration and chitinase activity were reduced by about half late in the growing season [48]. Using the nucleotide analog BrdU, they also observed a shift of the active fungal community away from a Thelephorid fungus and towards Ascomycetes and Zygomycetes. The relatively large change in community composition for a small increase in temperature implies a keystone species may have been lost, changing the functionality of the community and allowing an otherwise apparently small pressure to cascade.

Long-term field warming experiments in two temperate forested sites provide contrasting consequences of warming on microbial community composition. Following four years of $4{ }^{\circ} \mathrm{C}$ seasonal warming in the North Tyrolean Limestone Alps of Austria, Schindlbacher et al. found an increase in respiration and a non-significant increase in the rRNA:DNA ratio, another measure of activity [47]. There was no change in microbial biomass $C$ or the PLFA profile of the community as a whole, but there was a slight reduction in one PLFA associated with Actinomycetes and Gram-negative bacteria. These large increases in activity without much change in community identity suggest that warming improved conditions for the extant microbes without necessarily favoring one group over another, creating a more productive community. Alternatively, twenty years of warming at in a mixed deciduous stand at the Harvard Forest in Massachusetts led to an initial increase in respiration, followed by a subsequent decrease to control levels, and then an increase to above ambient again (Jerry Melillo, personal communication) [65]. This secondary increase in respiration may be explained under the community diversity hypothesis, which suggests that an overall increase in diversity has resulted in communities more resistant to higher and more extreme temperatures, or by the keystone species hypothesis, which suggests an increase in populations capable of degradation of more recalcitrant or previously physically protected soil carbon.

In a PLFA survey of the soil microbial community at this site just before soil respiration increased again, Frey et al. found evidence to support the keystone species hypothesis; while fungal and bacterial biomass decreased overall, there was a relative increase in Gram-positives and Actinomycetes, and a strong shift in PLFA profile despite no change in its diversity[6]. However, PLFA markers don't align well with phylogeny, and metabolic capacities vary non-randomly with phylogeny [17], so the data do not have enough resolution to decisively say whether whole community diversity or keystone species 
or functions are more important. Approaches that resolve finer changes in the microbial community, such as the metagenomic study we are completing at the Harvard Forest, are necessary if we are to better understand how microbial community composition affects soil carbon cycling, and how this will change under future climate.

\section{Mechanisms and Consequences of Warming Effects on Microbial Diversity}

A number of patterns emerge from the warming experiments above, the first of which is the lack of congruence between phylogenetic and functional diversity in the studies that measured both. The second pattern which emerges is that warming only sometimes affects the efficiency with which microbes convert carbon to biomass (carbon use efficiency), leading to shifts to a community characteristic of higher carbon use efficiency in some instances [6], with no predictable change [45] or a reduction in others $[47,56]$. The third pattern is that changes in microbial biomass are inconsistent, increasing at some sites $[43,44,56]$ and decreasing at others $[6,7,45,48,52]$ while at some sites there was no change [47] or a delayed response [42,64]. These inconsistencies may be methodological, sitespecific, or due to plant communities, which are well known links to below ground communities [66].

The lack of apparent congruence between phylogeny and function may be due to a "priming" effect not observed in all studies, where of one stress (for example, drought or fire) favors growth of species or functions that aid in providing resistance to a secondary stress (experimental warming). The primed species could derive from an initially diverse community (community diversity hypothesis), or a handful of organisms whose keystone role is their ability to weather the change in the environment. The increased diversity under drought and warming at the Great Plains site implies the former [43], while Yergeau's Antarctic and sub-Antarctic study indicates the latter. In this instance, warming reduced functional gene richness with no effect on microbial abundance or activity [56]. This may indicate that functional redundancy of the community was reduced by warming, and so the community may be more sensitive to further disturbances.

Carbon use efficiency is a key determinant of the long-term stability of carbon in soil, because microbial biomass, rather than recalcitrant plant matter, is most resistant to decay [67-69], and because microbial activity contributes significantly to terrestrial $\mathrm{CO}_{2}$ emissions [11,12]. Fierer et al. loosely classified bacteria into two groups based on the kinds of carbon they prefer and the efficiency with which they grow: copiotrophs, which grow rapidly but with low efficiency in high resource environments, and oligotrophs, which grow slowly but efficiently, thriving in low resource environments [70]. While Proteobacteria and Bacteroidetes tended towards copiotrophy, Acidobacteria, Verrucomicrobia, and the Gram-positive phyla Actinobacteria and Firmicutes leaned towards oligotrophy [70]. This implies that in environments where Bacteroidetes or $\beta$-Proteobacteria increase in relative abundance, carbon use efficiency has declined, favoring respiration, soil carbon loss, and positive feedbacks to climate. However, studies have provided mixed support for this so far (Table 2), with one study finding increased oligotrophs and lower biomass-specific respiration [6], while a second found no obvious change [45], and two more found increased copiotrophs [56] and biomass-specific respiration [47], an indication of low carbon use efficiency. Unfortunately, explicit conclusions regarding the effects of experimental warming on carbon use efficiency are few and far between, and inconsistencies in the methods used [8,71] precludes a more direct generalization of this microbial response. Furthermore, we have found that when we extract data from long-term warming 
studies and calculate proxies for carbon use efficiency, the magnitude and direction of the change depends on the metric used.

Changes in community structure may mask effects of warming on carbon use efficiency. All microbes inherently use labile substrates at a higher efficiency than complex ones [8,72], copiotrophs and oligotrophs differ in their substrates of choice [70], warming changes substrate quality [6,44], and carbon use efficiency decreases with temperature [72]. At the Harvard Forest, warming induced a significant shift in the microbial community [6], which was paralleled by a reduction in soil respiration and thermal adaptation of microbial carbon use efficiency on phenol [8]. It is unclear whether changes in carbon use efficiency are directly driven by changes in soil carbon chemistry or indirectly through warming- or substrate-mediated shifts in community structure. Unfortunately, in many cases the lack of taxonomic resolution in community data following disturbance prevents determination of whether shifts towards or away from oligotrophy was driven by changes in few keystone or many taxa.

It is likely edaphic factors such as secondary soil drying with warming, and changes in soil carbon availability, also play a role in microbial response to warming. In studies which test both warming and precipitation, it is often observed that precipitation treatment has an as strong if not stronger effect on soil microbial communities than warming $[45,73,74]$. However, this trend is muddied by inconsistencies in methods and associated errors in estimation. For example, PLFA profile can differ depending on the soil type and lipid extraction method used [75-77], "universal" primers for qPCR are never universal [41], and chloroform fumigation extraction efficiency is known to be pH sensitive [78]. However, microbes differ in their sensitivity to moisture stress [23,79], so moisture likely directly affect community composition and function, though the relative contributions of warming to drying are not well understood.

Inconsistencies in biomass may also be due to difference in plant effects across studies, many of which conclude that the strength and direction of the effect depends on how plants respond $[47,56,74,80]$. Soil warming induces nitrogen mineralization, which increases plant productivity $[12,44]$, and plant community composition often also changes with warming [81-84]. Since plants stressed by warming may increase production of structural carbohydrates and secondary compounds that reduce decomposability of senesced litter [85], species shifts may stimulate soil microbes and result in increased $\mathrm{N}$ mineralization as a side effect. In fact, while warming at the Great Plains site led to an increase in labile (and microbially available) carbon [44], it led to a reduced capacity to use labile substrates at the Harvard Forest [6], where fine root production [86] and soil carbon quality declined [7]. These differences in microbial activity are unlikely to be purely due to direct effects of increased nitrogen availability; rate of nitrogen cycling [11,44] and soil $\mathrm{N}$ availability $[42,44,87]$ have been affected similarly in both sites. While aboveground biomass removal has demonstrated that moderate warming is unlikely to have direct effects on the microbial community [42], direct determination of the relative role of changes in carbon and nitrogen availability on microbial community and activity is complicated by the fact that clipping reduces both $\mathrm{C}$ and $\mathrm{N}$ availability [88]. Nonetheless, the increase in diversity of genes involved in labile carbon utilization at the grassland site shows that many taxa were involved in the warming response, supporting the community diversity hypothesis.

The patterns outlined above have important implications for the carbon cycle and feedbacks to climate. Warming initially increases respiration, which, if heterotrophic soil microbes respond to 
warming on a time scale much faster than the dominant vegetation, would lead to depletion of the soil carbon pool. While this was true for one temperate forest [6,7], it was not the case for another [47,71], or in a subarctic heath, despite the apparently slow vegetation response there [53]. Microbes adapt to changes in carbon quality and temperature, through plasticity in their metabolisms or through shifts in community. If conditions favor more efficient microbes, more of the carbon assimilated will be directed to microbial biomass, a relatively stable carbon pool, but more biomass also means greater respiration and greater carbon loss. As soil carbon chemistry becomes more complex [85], or as temperatures increase, carbon use efficiency decreases independent of any change in the community [72]. Understanding which of these processes has dominated - as well as how diversity may affect the resistance of the soil microbial community to further change-is important for understanding how feedbacks to climate are mediated in the soil.

\section{Future Directions}

The lack of consistency in microbial community taxonomic response to warming among current field studies is likely due to many confounding factors, not limited to edaphic and methodological variables. To meet the goal of an improved understanding of processes driving the microbial response to warming, we need improved understanding of microbes, from the level of the gene and the physiology of individual microbes all the way to microbial community composition and interactions. Long term warming studies, especially at LTER sites such as the Harvard Forest, and the cross-latitudinal NEON sites, are especially suited for this because of the immense amount of biogeochemical and other site data.

To understand the role of microbes in ecosystem functioning, there are a wide range of choices to make in terms of measuring diversity, and in the end, relatively few direct measures of the contributions of microbes to ecosystem function. Microbes function on a scale which by definition we cannot see, yet drive the majority of energy and nutrient transformations which shape ecosystem function. New technologies such as NanoSIMS which, when coupled with FISH staining, enable us to visualize how microbes interact with each other and their environment, are changing this. Simpler techniques such as co-culture of novel isolates may also help improve our understanding for less money, in addition to "ground-truthing" some of the functions assigned to phylotypes in the masses of metagenomic data we are now able to collect.

Understanding the ecological function of microbial communities in their natural environment is essential, but microbial processes are often placed in a "black box" because the microbes present could not be determined or quantified. Rapid advances in genomic sequencing technology are transforming microbiology and in particular ecological research, and yet there is still value in making more traditional measures of microbial biomass and diversity in order to understand the portion of carbon or biomass that populations occupy, which is also a measure of functional potential. Though this is not always the case, genomic, genetic or informatics approach should be undertaken along with functional or absolute measures of diversity. Overall, we have much to learn about microbial diversity and its importance in the context of carbon cycling, and we have better tools than ever to do so. 


\section{Acknowledgments}

The authors wish to acknowledge the University of Massachusetts for funding.

\section{Conflict of Interest}

The authors declare no conflict of interest.

\section{References}

1. Davidson, E.A.; Janssens, I.A. Temperature sensitivity of soil carbon decomposition and feedbacks to climate change. Nature 2006, 440, 165-173.

2. Schlesinger, W.H.; Andrews, J.A. Soil respiration and the global carbon cycle. Biogeochemistry 2000, 48, 7-20.

3. Conrad, R. Soil microorganisms as controllers of atmospheric trace gases $\left(\mathrm{H}_{2}, \mathrm{CO}, \mathrm{CH}_{4}\right.$, OCS, $\mathrm{N}_{2} \mathrm{O}$, and NO). Microbiol. Rev. 1996, 60, 609-640.

4. Falkowski, P.G.; Fenchel, T.; Delong, E.F. The Microbial Engines That Drive Earth's Biogeochemical Cycles. Science 2008, 320, 1034-1039.

5. Canadell, J.G.; Quéré, C.L.; Raupach, M.R.; Field, C.B.; Buitenhuis, E.T.; Ciais, P.; Conway, T.J.; Gillett, N.P.; Houghton, R.A.; Marland, G. Contributions to accelerating atmospheric CO2 growth from economic activity, carbon intensity, and efficiency of natural sinks. Proc. Natl. Acad. Sci. USA 2007, 104, 18866-18870.

6. Frey, S.D.; Drijber, R.; Smith, H.; Melillo, J. Microbial biomass, functional capacity, and community structure after 12 years of soil warming. Soil Biol. Biochem. 2008, 40, 2904-2907.

7. Bradford, M.A.; Davies, C.A.; Frey, S.D.; Maddox, T.R.; Melillo, J.M.; Mohan, J.E.; Reynolds, J.F.; Treseder, K.K.; Wallenstein, M.D. Thermal adaptation of soil microbial respiration to elevated temperature. Ecol. Lett. 2008, 11, 1316-1327.

8. Frey, S.D.; Lee, J.; Melillo, J.M.; Six, J. Soil carbon cycling: the temperature response of microbial efficiency and its feedback to climate. Nat. Clim. Change 2013, 3, 395-398.

9. Treseder, K.K.; Balser, T.C.; Bradford, M.A.; Brodie, E.L.; Dubinsky, E.; Eviner, V.; Hofmockel, K.; Lennon, J.; Levine, U.; MacGregor, B.; et al. Integrating microbial ecology into ecosystem models: challenges and priorities. Biogeochemistry 2012, 109, 7-18.

10. Reid, A. Incorporating Microbial Processes into Climate Change Models. Available online: http://academy.asm.org/images/stories/documents/Incorporating_Microbial_Processes_Into_Clim ate_Models.pdf (accessed on 15 April 2013).

11. Melillo, J.M.; Steudler, P.A.; Aber, J.D.; Newkirk, K.M.; Lux, H.; Bowles, F.P.; Catricala, C.; Magill, A.H.; Ahrens, T.; Morrisseau, S. Soil Warming and Carbon-Cycle Feedbacks to the Climate System. Science 2002, 298, 2173-2176.

12. Melillo, J.M.; Butler, S.; Johnson, J.; Mohan, J.; Steudler, P.; Lux, H.; Burrows, E.; Bowles, F.; Smith, R.; Scott, L.; et al. Soil warming, carbon-nitrogen interactions, and forest carbon budgets. Proc. Natl. Acad. Sci. USA 2011, 108, 9508-9512.

13. Loreau, M.; Naeem, S.; Inchausti, P.; Bengtsson, J.; Grime, J.P.; Hector, A.; Hooper, D.U.; Huston, M.A.; Raffaelli, D.; Schmid, B.; et al. Biodiversity and Ecosystem Functioning: Current Knowledge and Future Challenges. Science 2001, 294, 804-808. 
14. Ptacnik, R.; Solimini, A.G.; Andersen, T.; Tamminen, T.; Brettum, P.; Lepistö, L.; Willén, E.; Rekolainen, S. Diversity predicts stability and resource use efficiency in natural phytoplankton communities. Proc. Natl. Acad. Sci. USA 2008, 105, 5134-5138.

15. Shade, A.; Peter, H.; Allison, S.D.; Baho, D.L.; Berga, M.; Bürgmann, H.; Huber, D.H.; Lennon, J.T.; Martiny, J.B.H.; Matulich, K.L.; et al. Fundamentals of microbial community resistance and resilience. Front. Aquat. Microbiol. 2012, 3, 417.

16. Gilbert, J.A.; Field, D.; Swift, P.; Thomas, S.; Cummings, D.; Temperton, B.; Weynberg, K.; Huse, S.; Hughes, M.; Joint, I.; et al. The Taxonomic and Functional Diversity of Microbes at a Temperate Coastal Site: A "Multi-Omic" Study of Seasonal and Diel Temporal Variation. PloS. One 2010, 5, e15545.

17. Martiny, A.C.; Treseder, K.; Pusch, G. Phylogenetic conservatism of functional traits in microorganisms. Isme. J. 2013, 7, 830-838.

18. Tilman, D.; Reich, P.B.; Knops, J.; Wedin, D.; Mielke, T.; Lehman, C. Diversity and Productivity in a Long-Term Grassland Experiment. Science 2001, 294, 843-845.

19. Tilman, D.; Downing, J.A. Biodiversity and stability in grasslands. Nature 1994, 367, 363-365.

20. Van Elsas, J.D.; Chiurazzi, M.; Mallon, C.A.; Elhottovā, D.; Krištůfek, V.; Salles, J.F. Microbial diversity determines the invasion of soil by a bacterial pathogen. Proc. Natl. Acad. Sci. USA. 2012, 109, 1159-1164.

21. Hutchinson, G.E. Concluding Remarks. Cold Spring Harb. Symp. Quant. Biol. 1957, 22, 415-427.

22. Fierer, N.; Lennon, J.T. The generation and maintenance of diversity in microbial communities. Am. J. Bot. 2011, 98, 439-448.

23. Lennon, J.T.; Aanderud, Z.T.; Lehmkuhl, B.K.; Schoolmaster, D.R., Jr. Mapping the niche space of soil microorganisms using taxonomy and traits. Ecology 2012, 93, 1867-1879.

24. Crowther, T.W.; Bradford, M.A. Thermal acclimation in widespread heterotrophic soil microbes. Ecol. Lett. 2013, 16, 469-477.

25. Rosenfeld, J.S. Functional redundancy in ecology and conservation. OIkos 2002, 98, 156-162.

26. Schimel, J.; Balser, T.C.; Wallenstein, M. Microbial stress-responses physiology and its implications for ecosystem function. Ecology 2007, 88, 1386-1394.

27. Rillig, M.C.; Wright, S.F.; Shaw, M.R.; Field, C.B. Artificial Climate Warming Positively Affects Arbuscular Mycorrhizae but Decreases Soil Aggregate Water Stability in an Annual Grassland. Oikos 2002, 97, 52-58.

28. Girvan, M.S.; Campbell, C.D.; Killham, K.; Prosser, J.I.; Glover, L.A. Bacterial diversity promotes community stability and functional resilience after perturbation. Environ. Microbiol. 2005, 7, 301-313.

29. Hol, W.H.G.; de Boer, W.; Termorshuizen, A.J.; Meyer, K.M.; Schneider, J.H. M.; van Dam, N.M.; van Veen, J.A.; van der Putten, W.H. Reduction of rare soil microbes modifies plant-herbivore interactions. Ecol. Lett. 2010, 13, 292-301.

30. Wertz, S.; Degrange, V.; Prosser, J.I.; Poly, F.; Commeaux, C.; Guillaumaud, N.; le Roux, X. Decline of soil microbial diversity does not influence the resistance and resilience of key soil microbial functional groups following a model disturbance. Environ. Microbiol. 2007, 9, 2211-2219.

31. Nielsen, U.; Ayres, E.; Wall, D.; Bardgett, R. Soil biodiversity and carbon cycling: a review and synthesis of studies examining diversity-function relationships. Eur. J. Soil Sci. 2011. 
32. Tyson, G.W.; Chapman, J.; Hugenholtz, P.; Allen, E.E.; Ram, R.J.; Richardson, P.M.; Solovyev, V.V.; Rubin, E.M.; Rokhsar, D.S.; Banfield, J.F. Community structure and metabolism through reconstruction of microbial genomes from the environment. Nature 2004, 428, 37-43.

33. Kato, S.; Haruta, S.; Cui, Z.J.; Ishii, M.; Igarashi, Y. Effective cellulose degradation by a mixedculture system composed of a cellulolytic Clostridium and aerobic non-cellulolytic bacteria. Fems. Microbiol. Ecol. 2004, 51, 133-142.

34. Pester, M.; Bittner, N.; Deevong, P.; Wagner, M.; Loy, A. A "rare biosphere"microorganism contributes to sulfate reduction in a peatland. Isme. J. 2010, 4, 1591-1602.

35. Fierer, N.; Jackson, R.B. The Diversity and Biogeography of Soil Bacterial Communities. Proc. Natl. Acad. Sci. USA. 2006, 103, 626-631.

36. Lozupone, C.A.; Knight, R. Global patterns in bacterial diversity. Proc. Natl. Acad. Sci.USA 2007, 104, 11436.

37. Lauber, C.L.; Hamady, M.; Knight, R.; Fierer, N. Pyrosequencing-based assessment of soil pH as a predictor of soil bacterial community structure at the continental scale. Appl. Environ. Microbiol. 2009, 75, 5111-5120.

38. Philippot, L.; Andersson, S.G.E.; Battin, T.J.; Prosser, J.I.; Schimel, J.P.; Whitman, W.B.; Hallin, S. The ecological coherence of high bacterial taxonomic ranks. Nat. Rev. Microbiol. 2010, 8, 523-529.

39. Fierer, N.; Lauber, C.L.; Ramirez, K.S.; Zaneveld, J.; Bradford, M.A.; Knight, R. Comparative metagenomic, phylogenetic and physiological analyses of soil microbial communities across nitrogen gradients. Isme. J. 2012, 6, 1007-1017.

40. Hanson, C.A.; Allison, S.D.; Bradford, M.A.; Wallenstein, M.D.; Treseder, K.K. Fungal Taxa Target Different Carbon Sources in Forest Soil. Ecosystems 2008, 11, 1157-1167.

41. Eilers, K.G.; Lauber, C.L.; Knight, R.; Fierer, N. Shifts in bacterial community structure associated with inputs of low molecular weight carbon compounds to soil. Soil Biol. Biochem. 2010, 42, 896-903.

42. Zhang, W.; Parker, K.M.; Luo, Y.; Wan, S.; Wallace, L.L.; Hu, S. Soil microbial responses to experimental warming and clipping in a tallgrass prairie. Global Change Biol. 2005, 11, 266-277.

43. Sheik, C.S.; Beasley, W.H.; Elshahed, M.S.; Zhou, X.; Luo, Y.; Krumholz, L.R. Effect of warming and drought on grassland microbial communities. Isme. J. 2011, 5, 1692-1700.

44. Zhou, J.; Xue, K.; Xie, J.; Deng, Y.; Wu, L.; Cheng, X.; Fei, S.; Deng, S.; He, Z.; Nostrand, J.D.V.; et al. Microbial mediation of carbon-cycle feedbacks to climate warming. Nat. Clim. Change 2012, 2, 106-110.

45. Gray, S.B.; Classen, A.T.; Kardol, P.; Yermakov, Z.; Mille, M.R. Multiple Climate Change Factors Interact to Alter Soil Microbial Community Structure in an Old-Field Ecosystem. Soil Sci. Soc. Am. J. 2011, 75, 2217.

46. Castro, H.F.; Classen, A.T.; Austin, E.E.; Norby, R.J.; Schadt, C.W. Soil Microbial Community Responses to Multiple Experimental Climate Change Drivers. Appl. Environ. Microbiol. 2010, 76, 999-1007.

47. Schindlbacher, A.; Rodler, A.; Kuffner, M.; Kitzler, B.; Sessitsch, A.; Zechmeister-Boltenstern, S. Experimental warming effects on the microbial community of a temperate mountain forest soil. Soil Biol. Biochem. 2011, 43, 1417-1425. 
48. Allison, S.D.; Treseder, K.K. Warming and drying suppress microbial activity and carbon cycling in boreal forest soils. Global Change Biol. 2008, 14, 2898-2909.

49. Allison, S.D.; McGuire, K.L.; Treseder, K.K. Resistance of microbial and soil properties to warming treatment seven years after boreal fire. Soil Biol. Biochem. 2010, 42, 1872-1878.

50. NOAA Climate Data Online (CDO)-COOP: 502339. Available online: http:/www.ncdc.noaa.gov/ cdo-web/confirmation/ (accessed on 15 April 2013).

51. Dorrepaal, E.; Toet, S.; van Logtestijn, R.S. P.; Swart, E.; van de Weg, M.J.; Callaghan, T.V.; Aerts, R. Carbon respiration from subsurface peat accelerated by climate warming in the subarctic. Nature 2009, 460, 616-619.

52. Weedon, J.T.; Kowalchuk, G.A.; Aerts, R.; van Hal, J.; van Logtestijn, R.; Taş, N.; Röling, W.; van Bodegom, P.M. Summer warming accelerates sub-arctic peatland nitrogen cycling without changing enzyme pools or microbial community structure. Global Change Biol. 2012, 18, 138-150.

53. Rinnan, R.; Michelsen, A.; Bååth, E.; Jonasson, S. Fifteen years of climate change manipulations alter soil microbial communities in a subarctic heath ecosystem. Global Change Biol. 2007, 13, $28-39$.

54. Bokhorst, S.; Huiskes, A.; Convey, P.; Aerts, R. The effect of environmental change on vascular plant and cryptogam communities from the Falkland Islands and the Maritime Antarctic. Bmc. Ecol. 2007, 7, 15.

55. Bokhorst, S.; Huiskes, A.; Convey, P.; Aerts, R. External nutrient inputs into terrestrial ecosystems of the Falkland Islands and the Maritime Antarctic region. Polar Biol. 2007, 30, 1315-1321.

56. Yergeau, E.; Bokhorst, S.; Kang, S.; Zhou, J.; Greer, C.W.; Aerts, R.; Kowalchuk, G.A. Shifts in soil microorganisms in response to warming are consistent across a range of Antarctic environments. Isme. J. 2012, 6, 692-702.

57. Rustad, L.E.; Campbell, J.L.; Marion, G.M.; Norby, R.J.; Mitchell, M.J.; Hartley, A.E.; Cornelissen, J.H.C.; Gurevitch, J.; Gcte-News A Meta-Analysis of the Response of Soil Respiration, Net Nitrogen Mineralization, and Aboveground Plant Growth to Experimental Ecosystem Warming. Oecologia 2001, 126, 543-562.

58. Wu, Z.; Dijkstra, P.; Koch, G.W.; Peñuelas, J.; Hungate, B.A. Responses of terrestrial ecosystems to temperature and precipitation change: a meta-analysis of experimental manipulation. Global Change Biol. 2011, 17, 927-942.

59. Zogg, G.P.; Zak, D.R.; Ringelberg, D.B.; White, D.C.; MacDonald, N.W.; Pregitzer, K.S. Compositional and Functional Shifts in Microbial Communities Due to Soil Warming. Soil Sci. Soc. Am. J. 1997, 61, 475-481.

60. Blankinship, J.; Niklaus, P.; Hungate, B. A meta-analysis of responses of soil biota to global change. Oecologia 2011, 165, 553-565.

61. Andrews, J.A.; Matamala, R.; Westover, K.M.; Schlesinger, W.H. Temperature effects on the diversity of soil heterotrophs and the $\delta 13 \mathrm{C}$ of soil-respired CO2. Soil Biol. Biochem. 2000, 32, 699-706.

62. Pettersson, M.; Bååth, E. Temperature-dependent changes in the soil bacterial community in limed and unlimed soil. Fems. Microbiol. Ecol. 2003, 45, 13-21. 
63. The Core Writing Team. Climate Change 2007: Synthesis Report Contribution of Working Groups I, II and III to the Fourth Assessment Report of the Intergovernmental Panel on Climate Change; IPCC: Geneva, Sweden, 2007; p. 104.

64. Jonasson, S.; Michelsen, A.; Schmidt, I.K.; Nielsen, E.V. Responses in microbes and platns to changed temperature, nutrient, and light regimes in the Arctic. Ecology 1999, 80, 1828-1843.

65. Foster, D.R.; Colburn, E.; Crone, E.; Ellison, A.; Hart, C.; Lambert, K.; Orwig, D.; Pallant, J.; Snow, P.; Stinson, K.; et al. New Science, Synthesis, Scholarship, and Strategic Vision for Society-HF LTER V 2012-2018 2012. Available online: http://harvardforest.fas.harvard.edu/sites/ harvardforest.fas.harvard.edu/files/publications/pdfs/LTERV-2012-proposal.pdf (accessed on 15 April 2013).

66. Wardle, D.A.; Bardgett, R.D.; Klironomos, J.N.; Setälä, H.; van der Putten, W.H.; Wall, D.H. Ecological linkages between aboveground and belowground biota. Science 2004, 304, 1629.

67. Conant, R.T.; Ryan, M.G.; Ågren, G.I.; Birge, H.E.; Davidson, E.A.; Eliasson, P.E.; Evans, S.E.; Frey, S.D.; Giardina, C.P.; Hopkins, F.M.; et al. Temperature and soil organic matter decomposition rates-synthesis of current knowledge and a way forward. Global Change Biol. 2011, 17, 3392-3404.

68. Schurig, C.; Smittenberg, R.H.; Berger, J.; Kraft, F.; Woche, S.; Goebel, M.-O.; Heipieper, H.J.; Miltner, A.; Kaestner, M. Microbial cell-envelope fragments and the formation of soil organic matter: a case study from a glacier forefield. Biogeochemistry 2013, 113, 595-612..

69. Cotrufo, M.F.; Wallenstein, M.D.; Boot, C.M.; Denef, K.; Paul, E. The Microbial EfficiencyMatrix Stabilization (MEMS) framework integrates plant litter decomposition with soil organic matter stabilization: Do labile plant inputs form stable soil organic matter? Global Change Biol. 2013, 19, 988-995.

70. Fierer, N.; Bradford, M.A.; Jackson, R.B. Toward an ecological classification of soil bacteria. Ecology 2007, 88, 1354-1364.

71. Schindlbacher, A.; Zechmeister-Boltenstern, S.; Jandl, R. Carbon losses due to soil warming: Do autotrophic and heterotrophic soil respiration respond equally? Global Change Biol. 2009, 15, 901-913.

72. Manzoni, S.; Taylor, P.; Richter, A.; Porporato, A.; Ågren, G.I. Environmental and stoichiometric controls on microbial carbon-use efficiency in soils. New Phytol. 2012, 196, 79-91.

73. Suseela, V.; Conant, R.T.; Wallenstein, M.D.; Dukes, J.S. Effects of soil moisture on the temperature sensitivity of heterotrophic respiration vary seasonally in an old-field climate change experiment. Global Change Biol. 2012, 18, 336-348.

74. Gutknecht, J.L.M.; Field, C.B.; Balser, T.C. Microbial communities and their responses to simulated global change fluctuate greatly over multiple years. Global Change Biol. 2012, 18, 2256-2269.

75. Nielsen, P.; Petersen, S.O. Ester-linked polar lipid fatty acid profiles of soil microbial communities: a comparison of extraction methods and evaluation of interference from humic acids. Soil Biol. Biochem. 2000, 32, 1241-1249.

76. Papadopoulou, E.S.; Karpouzas, D.G.; Menkissoglu-Spiroudi, U. Extraction Parameters Significantly Influence the Quantity and the Profile of PLFAs Extracted from Soils. Microb. Ecol. 2011, 62, 704-714. 
77. Chowdhury, T.R.; Dick, R.P. Standardizing methylation method during phospholipid fatty acid analysis to profile soil microbial communities. J. Microbiol. Methods 2012, 88, 285-291.

78. Haney, R.I.; Franzluebbers, A.; Hons, F.; Zuberer, D.A. Soil C extracted with water or $\mathrm{K}_{2} \mathrm{SO}_{4}: \mathrm{pH}$ effect on determination of microbial biomass? Can. J. Soil Sci. 1999, 79, 529-533.

79. Bates, S.T.; Clemente, J.C.; Flores, G.E.; Walters, W.A.; Parfrey, L.W.; Knight, R.; Fierer, N. Global biogeography of highly diverse protistan communities in soil. Isme. J. 2013, 7, 652-659.

80. Deslippe, J.R.; Egger, K.N.; Henry, G.H.R. Impacts of warming and fertilization on nitrogen-fixing microbial communities in the Canadian High Arctic. Fems. Microbiol. Ecol. 2005, 53, 41-50.

81. Harte, J.; Saleska, S.; Shih, T. Shifts in plant dominance control carbon-cycle responses to experimental warming and widespread drought. Environ. Res. Lett. 2006, 1, 014001.

82. Walker, M.D.; Wahren, C.H.; Hollister, R.D.; Henry, G.H.R.; Ahlquist, L.E.; Alatalo, J.M.; Bret-Harte, M.S.; Calef, M.P.; Callaghan, T.V.; Carroll, A.B.; et al. Plant community responses to experimental warming across the tundra biome. Proc. Natl. Acad. Sci. USA 2006, 103, 1342-1346.

83. Prasad, A.M.; Iverson, L.R.; Matthews, S.; Peters, M. A Climate Change Atlas for 134 Forest Tree Species of the Eastern United States; Available online: http://www.nrs.fs.fed.us/atlas/tree/ ( accessed on 15 April 2013).

84. Hoeppner, S.S.; Dukes, J.S. Interactive responses of old-field plant growth and composition to warming and precipitation. Global Change Biol. 2012, 18, 1754-1768.

85. Tharayil, N.; Suseela, V.; Triebwasser, D.J.; Preston, C.M.; Gerard, P.D.; Dukes, J.S. Changes in the structural composition and reactivity of Acer rubrum leaf litter tannins exposed to warming and altered precipitation: climatic stress-induced tannins are more reactive. New Phytol. 2011, $191,132-145$.

86. Zhou, Y.; Tang, J.; Melillo, J.M.; Butler, S.; Mohan, J.E. Root standing crop and chemistry after six years of soil warming in a temperate forest. Tree Physiol. 2011, 31, 707-717.

87. Bradford, M.A.; Watts, B.W.; Davies, C.A. Thermal adaptation of heterotrophic soil respiration in laboratory microcosms. Global Change Biol. 2010, 16, 1576-1588.

88. Belay-Tedla, A.; Zhou, X.; Su, B.; Wan, S.; Luo, Y. Labile, recalcitrant, and microbial carbon and nitrogen pools of a tallgrass prairie soil in the US Great Plains subjected to experimental warming and clipping. Soil Biol. Biochem. 2009, 41, 110-116.

(C) 2013 by the authors; licensee MDPI, Basel Switzerland. This article is an open access article distributed under the terms and conditions of the Creative Commons Attribution license (http://creativecommons.org/licenses/by/3.0/). 